MASKELYNE was born in London on Oct. 6, 1732, being the son of Edmund Maskelyne of Purton, Wiltshire. At the age of nine years he was sent to Westminster School, and it is said that, like Lalande and Messier, he was attracted to the study of astronomy by the solar eclipse of 1748. From Westminster School he proceeded to Cambridge, entering first Catherine Hall and then Trinity College, graduating as seventh wrangler in 1754. The following year he took holy orders and was appointed to a curacy at Barnet. He next took the degree of M.A., was made a fellow of Trinity, and in $\mathbf{1 7 5 8}$ became a fellow of the Royal Society, his first paper to the Society being written in 1760. Already known to Bradley, in 1761 Maskelyne was sent to St. Helena to observe the transit of Venus in order to determine the parallax of the sun, and two years later sailed as chaplain of the Princess Louisa on a voyage to Barbadoes, during which he tested the accuracy of Harrison's chronometer. The death of Bliss in 1765 leaving the office of Astronomer Royal vacant, Maskelyne was appointed to it. He had already in 1763 published the "British Mariner's Guide", and he was now able to prevail upon the Government to issue that eminently useful work the "Nautical Almanac". The almanac for 1767 was published in 1766, and for the succeeding forty-five years subsequent editions were superintended by Maskelyne. In connexion with his constant efforts to improve navigation, he edited the important lunar tables of the German astronomer Tobias Mayer (1723-1762); and obtained for Mayer's widow a grant of $£ 3000$, and for Euler, whose lunar theory he used, a grant of $£ 300$. Though in early life Maskelyne became a clergyman and afterwards received the degree of D.D., and was given the livings of Shrawardine, Shropshire, and North Runcton, Norfolk, most of his time was spent at Greenwich $\mathrm{Ob}$ servatory, and it was there he died on Feb. 9, 1811.

\section{International Congress of the History of Medicine}

THE ninth International Congress of the History of Medicine was held at Bucharest on Sept. 10-18, under the presidency of Dr. Victor Gomoiu, with King Carol II., who opened the Congress in state, as president of honour. Two principal subjects were chosen for discussion, namely, the evolution of medicine in the Balkan States, on which papers were read by representatives from Albania, Bulgaria, Czechoslovakia, Greece, Rumania, and Turkey, and the defence of Europe against plague, to which subject the chief contributions were made by Prof. Ricardo Jorge, director of public health at Lisbon; Prof. J. Guiart of Lyons, Prof. P. Capparoni of Rome, Prof. D. Giordano of Venice, Prof. G. Sticker of Würzburg, and Prof. L. Zembruski of Warsaw.

IN addition, a number of miscellaneous papers were presented, including the history of medicine and scientific criticism by Prof. A. Castiglioni of Padua, the development of operative gynæcology by Dr. I. Fischer of Vienna, the history of spectacles by Prof. W. Reis of Lemburg, Polydore Vergil by Prof. J. F. Fulton of Yale University, and Chaucer and medieval medicine by Dr. J. D. Rolleston, delegate of the British Government and the Royal Society of Medicine, who, like other national delegates, was elected honorary member of the Royal Rumanian Society of the History of Medicine and awarded the Rumanian Order of Cultural Merit (Class II.).

Dorrac the Congress visits were paid to the Faculty of Medicine, Prof. J. Cantacuzene's institute of serums and vaccines, Prof. M. Minovic's medico-legal institute, and various hospitals and museums, as well as to places of general interest. The last three days were spent in a motor tour through the country in the neighbourhood of Bucharest, with visits to sanatoria, the hospital at Sinaia, and the petroleum factory at Campina. A section of the Congress of the History of Sciences to be held next year at Warsaw will be devoted to the history of medicine, so that the next Congress of the International Society of the History of Medicine will not be held until 1935, when the meeting-place will probably be Madrid.

\section{Aeroplane Height Record}

ON Sept. 16, Mr. C. F. Uwins, chief test pilot of the Bristol Aeroplane Company, Ltd., attained a height of $43,976 \mathrm{ft}$. (about $8 \frac{1}{3}$ miles) in a Vickers Vespa biplane, and on Sept. 23 this height was officially confirmed as the absolute height record. The engine used was a Bristol Pegasus nine-cylinder air-cooled radial, which is now in common use in Service machines. The engine develops 900 h.p., and for the purpose of the attempt on the height record was fitted with a larger supercharger than is fitted normally. Mr. Uwins felt very little personal inconvenience at the great height achieved. He wore electrically warmed clothing and also had an oxygen supply apparatus. The previous absolute height record was that set up by Lieut. Apollo Soucek of the United States Navy, who reached a height of $43,181 \mathrm{ft}$. on June 4, 1930.

\section{Roman Road and Bridge, Rochdale}

The repair of the bridge carrying the Roman road over the stream at Black Castle Clough, Blackstone Edge, having been completed (see Nature of Sept. 3, p. 340), the bridge was declared open by Sir Alfred Law on Aug. 20, when members of the Rochdale Literary and Scientific Society and a deputation of Halifax antiquarians were present. Some interesting particulars relating to the Roman road and the bridge were given by Mr. W. H. Crump of Leeds. It would appear that the Roman road, which served the traffic between Yorkshire, Rochdale, and Cheshire, fell into disuse in the year 1740 and had not been repaired since that date. Other old bridges in the neighbourhood are a packhorse bridge which was about ten feet wide, and another, eight feet wide, which carried the road to Oldham. The width of the bridge, now restored to its original seventeen feet, was far greater than anything required to carry the traffic of the district at any time since Roman days. The course of the packhorse road to Lydgate can still be seen on the adjacent hillside. In places it crosses the Roman road, in others it is some distance away. Its relation to the bridge can be seen from the fact that part of the pack-

$$
\text { No. } 3283 \text {, VoL. 130] }
$$

